\title{
INSECT CONDITIONS IN PUERTO RICO DURING THE FISCAL YEAR, JULY 1, 1930 THRU JUNE 30, 1931
}

\author{
By M. D. LeONard
}

Entomologist, Insular Experiment Station, Río Piedras, P. R.

\section{ALFAUFA}

The alfalfa leaf-tyer, Dichomeris piperatus WIsm., was injurous on the experimental plots at the Isabela Sub-Station from April thru June but possibly not quite so injurious as last year, especially during April; no observations were made during the first half of the year but the insect was surely present.

The fall armyworm, Laphyma frugiperda S. \& A., did considerable damage in June, 1931 at the Isabela Sub-Station but was checked by being eaten by the giant toad, Bufo marinus L., which ate the caterpillars after the alfalfa was cut.

\section{BAMBOO}

The bamboo scale, Asterolecanium bambusae Bvd. (H. Morrison det.) was reported as heavily infesting bamboo at Cidra and at Mayagüez in August and September (A. S. Mills) and as infesting bamboo at Maricao in January (A. G. Harley). It was however undoubtedly generally distributed and common throughout the Island.

\section{BANANA}

The banana root-borer, Cosmopolites sordidus Germ., was more or less injurious throughout nearly all parts of the Island, its status undoubtedly being about the same as during the previous year. During March and April however a survey made on about 800 farms compirsing about 50,000 acres in the Districts of Ponce, Guayanilla and Penuelas which were previously thought to be free of the pest or nearly so, showed that Ponce ranged from $7-20$ per cent infested and initial infestations were found scattered thruout the other two Districts.

The West Indian cane weevil; Metamasius hemipterus L. was reported as abundant and generally distributed in the bananas examined in the above survey. 
BEANS

The lima bean pod-borer, Maruca testulalis Geyer, was undoubtedly present wherever lima or string beans were grówn in the Island but has actually been observed only at Río Piedras, Isabela, Mayagüez and Cidra. All indications point to the fact that it is more abundant during the fall and winter months and scarce to sometimes absent during the summer. The fact that beans both string and limas are more commonly grown during the winter is undoubtedly largely but probably not entirely responsible for this difference in abundance.

Another bean pod-borer, Etiella zinckenella Treit., has been found to be widely distributed and fairly abundant at least in the lower parts of the Island; it also occurs in Vieques Island. During the spring it was considerably more common at Isabela than Maruca as a bean pod-borer and the same was true but possibly to a somewhat less extent at Río Piedras during the previous fall and summer. We have reared it in the latter place during the summer and fall of 1931 from lima beans crotalaria, cowpeas, and pigeon peas, in which latter it is even more common than in lima beans.

The cowpea pod and stalk borer, Fundella cistipennis Dyar., was reared a number of times from lima beans during May 1930 and altho it was not observed infesting beans during the past fiscal year it was undoubtedly present in fair numbers.

A leaf beetle, Ceratoma denticornis Fab., was fairly common on string beans at the Station during March and April but apparently not doing much damage. No other definite observations were made during the year but the insect was probably fairly common and general as is usual wherever string beans were grown.

A leaf-beetle, Diabrotica graminea Baly, was present and fairly common in several places observed but doing only moderate damage to string beans. It was also recorded on Irish potatoes and mung beans in June, both of which see.

The bean lace-bug, Corythucha gossypii Fab., has been moderate to abundant and injurious to both lima and string beans wherever grown and more or less thruout the year, altho as usual it was more abundant and injurious during the summer months.

The corn earworm, Heliothis obsoleta Fab., was found lightly infesting about 1 per cent of the pods at harvest time of about 1 acre of string beans at the Station at Río Piedras.

A leafhopper, Empoasca fabalis De Long, was moderated to abundant and injurious to both lima and string beans wherever grown thruout the year; several patches of string beans observed which had 
not been sprayed were practically destroyed by the insects which were extremely abundant.

The bean leaf-roller, Goniurus proteus L., was present in most plantings of both string and lima beans observed during the year but as a rule not doing a great deal of damage.

The bean leaf-webber, Lamprosema indicata Fab., was only observed doing moderate damage at Río Piedras in several plantings of lima beans during the late fall.

Larvae of the greenhouse leaf-tyer, Phlyctaenia rubigalis Gn., were observed as doing considerable damage to the foliage of string beans in January and February.

Larvae of the rattlebox moth, Utethesia ornatrix L., were abundant in string-bean pods at Río Piedras in January and February.

"Vaquitas," Diaprepes spengleri L., were observed eating the leaves of string beans to a considerable extent at Isabela in January or February.

The bean aphid, Aphis rumicis L., was observed lightly infesting a 1/2-acre patch of string beans at Manatí on Mar. 7, 1931 (A. S. Mills \& E. G. Anderson; P. W. Mason det.). This is apparently the first definite record of the insect for Porto Rico.

The eggplant stem-borer, Baris torquatus Oliv., on beans (See under eggplant.

\section{BEETS}

A leaf-beetle, Disonycha laevigata Jacoby, was abundant and doing considerable damage to a fair-sized garden patch of both beets and Swiss chard at Palo Seco on Aug. 29, 1930. The grower stated that these beetles had troubled him for several years and had necessitated constant control measures (M. D. Leonard \& A. S. Mills).

Moths of the smaller beet webworm, Hymenia fascialis Cramer, were not uncommon at lights at Aguirre the end of June. Infested beets were only observed at Palo Seco, mentioned above, at which time they, as well as the Swiss chard, were infested to a considerable extent with this webworm.

\section{BIDENS PILOSA}

See Protalebra brasiliensis De Long under SUgaR CaNE.

\section{CABBAGE}

The diamond black moth, Plutella maculipennis Curtis, was abundant and injurious thruout the year wherever cabbage was grown, but as usual was less active during the winter months. 
124 THE JOURNAL OF THE DEPARTMENT OF AGRIOULTURE OF P. R.

A leaf-miner, probably Agromyza inaequalis Malloch, was fairly common on plants grown at the Station in Río Piedras in April; definite observations were not made during the rest of the year.

A weevil, Lachnopus curvipes Fab., was found on a cabbage plant at Río Piedras, Jan. 5, 1931 (Mills and Anderson; L. L. Buchannan det.).

\section{CACTUS}

The eactus scale, Diaspis echinocacti opuntiae Ckll. (Morrison det.) on a cactus (Opuntia ?), Coamo Sept. 30, 1930 (A. G. Harley) and one plant of Opuntia brasiliense, moderately infested in Santurce, Mar. 24, 1931 (R. Faxon and A. S. Mills).

\section{CARNATION}

A scale insect, Pseudoparlatoria ostreata Clkll. (Morrison det.), was submitted the end of June by M. A. Díaz of the Department of Agriculture with the report that it was badly infesting a number of. plants in a garden at Martin Peña.

\section{CASSAVA}

Red spiders, Tetranychus sp., were somewhat less abundant and injurious during the fall than during the spring and summer of 1930) due to more rain in the fall.

The cassava shoot-borer, Lonchaea chalybea Weid., was common on isolated plants at the Station thruout the year.

\section{GASTOR BEAN}

The bean lace-bug, Corythucha gossypii Fab., was present in moderate numbers on castor-bean foliage in several localities observed in the late summer of 1930 but was undoubtedly present to a.greater or less extent in all parts of the Island thruout the year.

\section{CHAYOTE}

The pickle worm, Diaphania nitidalis Cramer, was first found infesting about $20 \mathrm{per}$ cent of the fruits in one of the largest plant. ings in Lares in October, 1930. From then on into March fruits were found at frequent intervals in the market in Río Piedras averaging 5-10 per cent infested. Since that time no observations have been made First record of definite food-plant or locality for Porto Rico. 


\section{CITRUS}

Scale insects, principally the purple scale, Lepidosaphes becliii Newm. and the Florida red scale, Chrysomphalus ficus Ashm. were apparently general and about as injurious as usual, several large growers reporting them worse than during the previous year and other grower's as not so abundant.

The green scale, Coccus viridis Green, was obtained early in June lightly infesting a number of young grapefruit trees at the Isabela Sub-Station. It was probably on eitrus in other places but observations were not made except near Isabela where during the month infestations of green scale almost disappeared from at least 4 grapefruit plantings observed due to heavy rains, growth of windbreaks and spraying with oil combined.

The woolly white fly, Aleurothrixus floccosus Mask., moderately infested about 20 young Meyer lemon trees on the Station grounds in April at Río Piedras.

The rust mite, "Phyllocoptes oleivorus Ashm., was apparently not as injurious on the whole as during the previous year.

The "vaquita grande", Diaprepes spengleri L., did considerable damage as usual especially during May and June to the foliage in the citrus sections by entirely stripping off new growths and by the larvae injuring the roots. It was reported that in the Bayamón section the adults caused considerable drop of young grapefruits (tho no more than usual) by cutting them off at the point of attachment to the stems.

The "vaquita verde", Exopthalmodes roseipes Chev., also did some damage to foliage in the main citrus section during the summer and according to one of the best growers caused some injury to the fruits in June 1931 in his locality.

June beetles, undoubtedly involving mostly Phyllophaga vandinei Smyth, and $P$. citri Smyth, were injurious to both young and old trees due to feeding of the adults on the leaves (mostly during May and June) and the larvae on the roots. In January about $1 / 3$ of 30,000 grape fruit seedlings were reported killed by white grubs in a nursery at Bayamón. It is felt, however, that these insects have been less injurious during the past 2 or 3 years than formerly in at least the older parts of the citrus-growing section around Bayamón due to the introduction in 1926 of the toad, Bufo marinus L., in small numbers into several groves and their subsequent great increase. One large grower stated that he had found as high as 20 beetles in the stomach of a single toad. 
Ants, especially the brown ant, or "hormiga brava", Solenopsis geminata Fab., were injurious to citrus as usual and required control measures by many growers.

Thrips injury to citrus fruits has only once before been recorded in Porto Rico. During the past year the writer has several times observed thrips in fair numbers in the blossoms but no specimens were collected for determination. Many grape-fruits have also been seen in several packing houses which certainly show characteristic "thrips injury" but more detailed observations will have to be made.

The bean lace-bug, Corythucha gossypii Fab., was found for the first time in Porto Rico moderately infesting several young lemon and orange trees at Isabela in April; in May a light infestation of several young grapefruit trees was observed at Río Piedras. It is interesting to note that recently Brunner observed the insect on citron foliage in Cuba.

A very common injury to oranges has been prevalent again this past year in several parts of the citrus growing section, especially the Eastern part. When the fruits are fully-grown but still green to nearly ripe a very small hole is often found underneath which the pulp becomes soft and juicy and breaks down. Often these holes are enlarged apparently by birds which probably peck into them to extract the larvae of such scavangers as Nitidulid beetles, Drosophila larvae and especially larvae of the spotted rootfly, Euxesta notata Wiedemann, which latter has often been found therein and adults reared. The real cause of the original small holes is not known, but certainly the Euxesta fly is not primarily responsible. Considerable loss occurred to a number of growers during the year.

A leaf-footed plant-bug, Loptoglossus gonagra Fab., did considerable injury from the latter part of November into December in a 65-acre grape-fruit grove at Pueblo Viejo. At the same time about 10 acres of grapefruits were attacked a little west of Bayamón and caused about 10 per cent of the fruits to drop. The bugs were in enormous numbers and were breeding on the wild balsam apple, Momordica charantia L., which was very common in the grove. The adults flew to the ripening fruits and made small feeding punctures under which the pulp became broken down and often had a slightly rotten odor and a bitter taste. By the first of January all trouble was over and it was reported that very few of the bugs could be found in either grove.

The Fulgorids, Bothriocera bicornis Fab, and Ormenis infuscata Stal. (P. W. Oman det.), on grapefruit leaves at Añasco. Nov. 5. 1930 (A. G. Harley). 
CANNA

The canna leaf-roller, Calpodes ethlius Cramer, was observed early in June to be moderately infesting a number of plants at Isabela.

\section{COCONUT}

Rhinoceros beetle, Strataegus quadrifoveatus P. de B., was generally distributed and destructive thruout the whole constal area of the Island. It was most abundant however in the coconut-grrowing sections of the following municipalities: (Western Section) Aguadilla, Aguada, Moca, Rincón, Añasco, Mayagüez, Hormigueros, Cabo Rojo and Lajas; (Northern Section) Barceloneta, Manatí, Vega Baja, Vega Alta, Carolina and Loíza; (Eastern Section) Yabucoa and Humacao. In these an intensive clean-up campaign was carried on by the Agricultural Extension Division from September to July during which there were collected a total of 370,844 larvae and of 27,498 beetles by boys to whom a total of $\$ 3,354.49$ was paid. They received from 5 to 10 cents per dozen.

The coconut scale, Aspidiotus destructor Signoret, according to Mr. Ferdinand Méndez, in charge of the coconut bud-rot elean-up campaign, was generally distributed throughout the Island. It was particularly injurious however at Boquerón near Cabo Rojo and at Patillas. At Boquerón serious damage was done to a young plantation and at Patillas many old bearing trees were badly infested.

\section{COFFEE}

Adults of the coffee stem-borer, Apate francisca Fab., were taken from dead twigs of tamarind at Tallaboa by A. G. Harley on Nov. 8, 1930 (W. S. Fisher det.). In March there was a severe infestation at Lares in which about 100 coffee trees on about 1 acre were injured; guava were also injured and an orange, an aguacate and some pomarrosa (Jambos Jambos) fence posts were also slightlly injured; burrows were also found in two achiote trees (Bixa orellana L.) and 50 infested pigeon-pea plants had been ent and burned. A couple of weeks later early in April the infestation had apparently subsided. A few coffee trees were reported infested at Guayanilla during April.

The green scale, Coccus viridis Green, was collected by Faxon, Harley and Mills of the U.S. P. Q. \& C. A., (det. by Morrison,) on June 25, 1931, on coffee at Maricao but abundance was not stated. In April it was observed lightly infesting several varieties at the Station in Rio Piedras and in June a number of young grapefruit 
trees at the Isabela Sub-Station were found lightly infested. It is undoubtedly widely distributed in Porto Rico on coffee and citrus.

The coffee leaf miner, Leucopter a coffeella Staint., was present in greater or less abundance in all colfee plantations thruout the year, being more abundant and injurious, as usual, in the dryer sections; systematic spraying was necessary in seedbeds thruout the Island. In Oetober and November cocoons were collected at Lares to determine the percentage of parasitism. These were taken only from a dry locality. Out of 871 cocoons 645 moths emerged and only $T$ parasites, all of which were Chrysocharis lividus Cresson.

The coffee shade tree ant or "hormiguilla" Myrmelachista ambigua Forel var. ramulorum Wheeler, was generally present thruout the coffee growing sections but during last year and since the hurricane of 1928 has been less abundant and injurious than formerly due to the destruction of so many of the large coffee shade trees; the ants are less abundant or at least less in evidence during wet weather.

The hemispherical scale, Saissetia hemispherica Targ., was reported abundant and causing considerable sooty mould on coffee trees at Guayanilla during April.

A light infestation of Pseudococcus citri Risso, was observed cluring April on a small variety planting at the Station at Río Piedras.

Mothis of the colfee stem-borer, Psychonoctua personalis Grote, were caught at light at Cataño on April 24, 1930; Coamo Springs, April 4, 1930 and at Puerto Real, Vieques Island, on April 28-29, 1930 , as well as at Aguirre, May 22, but only a few specimens atlogether. The work of the larva was not observed during the vear but it was undoubtedly present in the coffee sections to some extent as usual.

Several adults of a leaf-hopper, Cicadella coffeacola Doz., were taken on a coffee tree at Maricao, Dec. 11, 1930 (A. G. Harley; P. W. Oman det.).

COFFEE SHADE-'TREES

Glyricidia sepium (Jacq.) Stend. In June a scale, Howardia biclavis Comst., was noticed as abundant on a number of these shade trees in a good-sized experimental plot of coffee at the Mayagüez Station; it had been present for several years according to T. B. MeClelland and had considerably interfered with the growth of the trees.

Cedro hembra, Turpinia paniculata Vent. A lepidopterous shootborer, Hypsiphyla grandella Zell.. (a Phyeitid; Heimich det.) was 
reported during June as having done considerable damage to about 4,000 young trees at Jayuya and to about 1,000 young trees recently planted at Adjuntas in June, 1931; a number of young trees were moderately infested at Lares.

\section{CORN}

The coln earworm, Heliothis obsoleta Fab., was without doubt generally present and injurious wherever corn was grown altho but few specific reports were received or observations made.

\section{COTTON}

The pink boll-worm, Pectinophora gossypiella Saund, has been for more abundant than ever before and assumed the proportions of a first-class pest of cotton. Because of a prolonged drought on the South Coast which materially reduced the yield, it is difficult to estimate with certainty the extent of the damage by the pink bollworm but at least 15 to 20 per cent if not more of the total crop of about 10,000 acres of Sea Island Cotton must have been destroyed. Infestation was noticed in the first cotton to be picked in late December and early January and it grew progressively worse so that not more than one or two piekings could be made from many fields which developed 80,90 and even 100 per cent infested bolls. often two or three larvae infesting a single boll. The above applies also to the cotton in the Carolina section on the North Coast which, however, was planted at about the same time as that in the South Coast. No cotton was bought after May 15 but it was the end of June before the destruction of the plants was anything like complete.

In the North-Coast cotton-growing section the infestation apparently began to appear early in May or late in April and by the end of May the infestation, tho still light, was apparently general. Since then it gradually increased in severity until by the first of July many fields showed a high percentage of infestation, the damage being fully as great as that suffered by the South-Coast crop. The 1930-crop on the North Coast became fairly generally tho lightly infested towards the end of the crop in the early fall but little loss was occasioned.

About 35 acres of cotton were grown on Vieques Island for the first time in some years; it was harvested in April and May and according to the local Agricultural Agent it was all badly infested, several fields having 100 per cent of the bolls infested and only about one picking was obtained from most of the individual plantings, each of which was small. 
The cotton leaf-worm, Alabama argillacea Hübner, occurred in destructive outbreaks thruout the year. In the South Coast outbreaks occurred from about mid October (when early plants were large enuf) thru March. None requiring poisoning were reported for April or May altho the leaf worm was present, but especially in the former month a large percentage of the erop had already been picked or was so nearly done that growers would naturally not feel it worth while to use poison even if the insect were present in some numbers. In the North Coast a moderate outbreak occurred near Isabela during March and considerable outbreaks were reported in various places during April, May and June 1931. Considerable poison was used during July and August. 1930 in the main part of the North-Coast Section, and in September an outbreak occurred at Canóvanas a little east of San Juan.

According to the local Agricultural Agent on Vieques Island no leaf worm was observed on the approximately 35 acres of cotton growing on the Island during the fall to spring of 1930-31 altho careful watch was kept for an outbreak thruout the growing season.

Stainers, Dysdercus spp., have been generally present and often abundant but not usually doing any undue amount of damage, altho there has been some loss from reduction in the quality of the lint. By far the most common species is $D$. andreae $\mathrm{L}$. and altho $D$. neglectus Uhl. is probably frequently associated with it, but one authentic record of its occurrence was obtained. This was at Carolina from April thru June and in this case neglectus was apparently the dominent species present in several fields at least.

Blister mite, Eriophyes gossypii Banks, has been present on young to old plants in all sections thruout the growing season but not very injurious; occasional plants however are found badly infested and sometimes young plants have been badly dwarfed or even entirely killed.

The black seale, Saissetia nigra Neitner, was observed in a number of fields in both the North and South Sections but was not abundant except in one or two cases in the South Coast where a number of old plants were thickly encrusted and apparently considerably weakened by the attack.

The bean lace-bug, Corythucha gossypii Fab., was occasionally observed lightly infesting the foliage of a few plants in several places.

A leaf-hopper, Empoasca sp. was present in small numbers in many fields examined.

The cotton aphis, Aphis gossypii Glov., was present in small numbers in a number of fields. 
The cotton leaf-miner, Nepticula gossypii Forbes and Leonard, was present, light to abundant, in many fields in the South Coast but like the previous year was not observed in the North Coast.

A scavenger caterpillar, Pyroderces rileyi Wlsm., was often ob- 1 served working in old or decayed cotton bolls.

"Changas", Scapteriscus vicinus Scudd., were reported as doing considerable injury to young cotton plants at Isabela in the spring of 1931.

\section{COWPEAS}

The cowpea pod and stalk borer, Fundella cistipennis Dyar, was repeatedly reared from cowpeas at Río Piedras during the summer and fall.

A bean pod-borer, Etiella zinckenella Treit., was several times reared during the summer and fall from cowpea pods at Río Piedras.

The scavenger caterpillar, Pyroderces rileyi Wlsm., infesting dry cowpea stems from Vieques Island, Jan. 7, 1931. (A. S. Mills.)

\section{CROTALARIA}

The rattlebox moth, Utethesia ornatrix L., has been abundant and destructive as usual, at least at the lower elevation, one grower having reported only 7 tons of seed from 60 acres at Bayamón during February and March, which was only about $1 / 3$ normal yield. Another grower at Adjuntas (about 2,000 ft. elevation) reported, however, little damage. The former grower stated that the poorest yields due to activities of the larvae were obtained from seed planted in April, May and June. Since it takes 4-5 months to mature a crop of seed this crop came off in August and September thru October and November and therefore presumably the maximum activity of the larvae would come somewhat in advance of the harvest period.

A bean pod-borer, Maruca testulalis Geyer, was found once at Río Piedras in March, a single larva boring within a pod.

A bean pod-borer, Etiella zinckenella Treit., was several times reared from Crotalaria pods at Río Piedras during the summer.

A gelechiid pod-borer, Brachyachma palpigera Wlsm., was several times found in the dry pods in the late summer and fall from Pueblo. Viejo and Bayamón.

A Mycetophagid beetle, Typhaea fumata L., (W. S. Fisher det.) was collected-several specimens-in the pods at Pueblo Viejo, Aug. 14, 1930. Not in Wolcott's "List". 
132 THE JOURNAL OF THE DEPARTMENT OF AGRIOULTURE OF $P$. $R$

\section{CUCUMBER AND MELONS}

The melon worm, Diaphania hyalinata L., was observed moderately abundant in squash and cucumber at Manatí and in eueumber at Arecibo in January and February and very injurious to melon and cantaloupes near Aguadilla in May.

The melon aphis, Aphis gossypii Glov., was present and often injurious in several places but probably was a factor wherever cucurbiits were raised.

A leaf-hopper, Agallia albidula Uhler, was common on watermelon vines at Arecibo on Nov. 4, 1930 (Mills and Anderson; P. W. Oman det.). This species has apparently not been definitely before recorded from Porto Rico.

An adult of the weevil, Lachnopus curvipes Fab., was found on a watermelon leaf at Arecibo on November 11, 1930 (Mills and Anderson; Buchamnan det.) but it probably was not feeding on this plant.

The pickle worm, Diaphania nitidalis Stoll, was moderately infesting a patch of cucumbers at Arecibo in March 1931; adults were reared (A. S. Mills).

A leaf beetle, Diabrotica innuba Fab., found on the leaves in a watermelon patch at Barceloneta, Dec. 12, 1930 ( $R$. Faxon and $A$ S. Mills; H. S. Barber det.).

EGGI'ANT

The leaf-tyer, Psara perusialis Walk., moderately infested a fairsized patch at Río Piedras on Jan. 5 (Anderson and Mills; Heinrich det.). At the Station it was present and troublesome thruout the year.

The eggplant lace-bug, Corythaica monacha Stal., was generally present and injurious thruout the year. It was especially noticed as abundant at Palo Seco in August and at Río Piedras, Dorado and Fumacao during January and February. The insect was also to be found in greater or less abundance thruout the Island on its favorite wild food plant, Solanum torvum.

Fleabeetles, Epitrix cucumeris Harr. and E. parvula Fab., were more or less abundant in several localities examined, especially during the fall and winter; more damage was done to seedlings than plants in the field.

Aphids, Myzus persicae Sulz. and Aphis gossypii Glov., were observed in small numbers at Río Piedras, Dorado, Humacao and several other places on the Island during January and February. 
Adults of a coreid bug, Corizus hyalinus Fab., were collected from eggplant leaves at Caguas, Feb. 18, 1931 (R. Faxon and A. S. Mills; H. G. Barber det.); previously recorded here only from Río Piedras in June, 1916 as "very abundant on weeds in a garden, some feed. ing on tomato".

Red spiders, Tetranychus sp., were abundant and injurious to plants at the Station at Río Piedras during the spring of 1931.

Cut worms, Noctuidae, caused about 10 per cent loss of plants in the seed beds grown in the greenhouse at the Station during September and October; they were also injurious in the field to the young plants soon after transplanting.

A leaf-beetle, Diabrotica graminea Baly, was more or less injurious at the Station thruout the year, feeding on the flowers and deforming the fruits.

An adult of the egg-plant borer, Baris torquata Oliv, was found resting on a bean leaf at Río Piedras on Feb. 14, 1931 (A. S. Mills; L. L. Buchannan det.).

A leaf-hopper, Oicadellidae, was generally present throughout the year in small numbers at the Station at Río Piedras but doing little damage.

GRAPIS

The brown aphid, Aphis illinoisensis Shimer (P. W. Mason det.) was observed lightly infesting a small grape arbor in the Melia Hotel in Ponce on May 1, 1931 (E. H. Twight of Ins. Expt. Sta.).

\section{GRASSES}

The gramma Psara, Psara phaeopteralis Guenée, was reported as abundant and injurious near Isabela the latter part of June on St. Augustine grass; about the same time it was very abundant on the some food plant at Aguirre. The adults and larvae were also abundant during June in large patches of a weed, Gonphwena dispersa at El Morro in San Juan.

"Changas", Scapteriscus vicimus Scudd., did great injury from September 1930 thru February, 1931 to a good-sized lawn near Río Piedras, composed of two mixed grasses locally called "horquetilla", Chloris radiata and C. paraguaiensis (Pedro Osuna of Ins. Expt. Sta.).

\section{GUAVA}

The hemispherical seale, Saissetia hemispherica Targ. (H. Morrison det.), was reported as infesting all the fruits on one tree at Juana Díaz, Mareh 13, 1931 (Faxon and Mills). 
134 THE JOURNAL OF THE DEPARTMENT OF AGRICULTURE OF P. R.

A West Indian fruit-fly, Anastrepha sp. was found breeding in guava fruits during part of the year (see discussion under these two species on page_---).

\section{MUNG BEANS (Phaseolus aureus)}

The leaf-beetle, Diabrotica graminea Baly, was numerous on a small patch at the Station at Río Piedras in June, feeding on the blossoms and leaves.

OKRA

The leaf-beetle, Diabrotica graminea Baly, was observed moderately infecting a 1-acre planting at Trujillo Alto in March and again in July.

A leaf-hopper, Cicadalla sirena Stal., was lightly infesting a 1/2acre patch of okra at Trujillo Alto on Mar. 10, 1931 (Anderson and Mills; P. W. Oman det.). This is the first record for okra in Porto Rico.

The hemispherical scale, Saissetia hemispherica Targ., was found to be lightly infesting about a 1-acre planting at Trujillo Alto on March 27 (R. Faxon and A. S. Mills; H. Morrison det.).

Aphis gossypii Glov. heavily infested the above patch on the same date (Faxon and Mills; P. W. Mason det.).

The black scale, Saissetia oleae Bern. (Morrison det.), was observed lightly infesting the same patch on March 10, 1931 (Anderson and Mills).

\section{ONION}

The onion thrips, Thrips tabaci Lind., was present as usual wherever onions are grown and often very injurious, more so of course where control measures were not well carried out and in the drier sections and periods.

\section{PALMS}

The palm aphid, Cerataphis lantanae Boisd., was found badly infesting a plant of Cyrtopodium Woodfordia in Santurce on March 4, 1931 (Faxon and Mills; H. Morrison det.).

\section{PAPAYA}

The papaya fruit-fly, Toxotrypana curvicauda Gerst., had been previously reported only from Mayagüez. A careful survey of many localities in the Island during the end of July and early August failed to discover infested fruits. Early in September however, it was found at Lares and later in the month a number of infested fruits 
were found at this town and also in Mayagüez but at no other point in the Island. It was reported again from Lares in January and February. Also 1 out of 7 small green fruits examined in the Mayagüez market on Jan. 6 by Mr. Harley contained 6 larvae. During May and June 1931 many fruits were reported badly infested at one farm near Ponce.

The West Indian peach scale, Aulacaspis pentagona Targ., has been observed during the period covered in almost every place in which papayas were observed thruout the Island, often almost entirely encrusting the trunk and branches and many fruits.

Another scale, Pseudoparlatoria ostreata Chll., was observed as very abundant at Ponce and several other places on the South Coast in the fall and also abundant at Isabela in May. It is undoutedly widely distributed and abundant on papaya.

The bean lace-bug, Corythucha gossypii Fab., was observed to be scarce to fairly abundant in all stages on the leaves in several widely separated localities during July and August 1930.

\section{PASSIFLORA}

Two scale insects, Pseudoparlatoria ostreata Ckll., and Howardia biclavis Comst. (both Morrison det.), were found to be so heavily infesting eight vines at Río Piedras on July 7 that one vine had died (A. S. Mills).

A few caterpillars of Dione vanillae L. were observed eating the leaves of one vine at Río Piedras on July 13 (A. S. Mills).

\section{BLACK-EYE PEA (Vigna unguiculata)}

The cowpea pod and stalk borer, Fundella cistipennis Dyar was reported by E. Molinary and A. Riollano of the Ins. Dept. Agr. to have rendered worthless most of the seed on about 10 acres out of a total planting of about 25 acres at Puerto Real, Vieques Island, in February or March.

PEAS

Specimens of Blissus leucopterus var. insularis Barber, found on a garden pea plant from Vieques Island, Sept. 10, 1930 (A. S. Mills; H. G. Barber det.).

\section{PEPPERS}

A light infestation of corn earworm, Heliothis obsoleta Fab., was observed at Río Piedras in January or February. Larvae were also found infesting peppers offered for shipment to the States from Río Piedras in December 1930. 
A stink bug, Arvelius albopunctatus DeG. lightly infested peppers at Corozal in January or February.

A mealy-bug, Aleurotrachelus trachoides (Back.) moderately infested the leaves in a 2-acre planting at Arecibo on Feb. 24, 1931 (Anderson and Mills det. G. B. Merrill).

A Pentatomid bug, Euschistus crenator Fab. was observed in all stages feeding on the fruits in a 2-acre planting at Arecibo on Feb. 24,1930 ; about 15 per cent of the plants were affected (E. G. Anderson and A. S. Mills; H. G. Barber det.).

An adult of Nezara viridula $\mathrm{L}$. was taken feeding on a pepper fruit at Arecibo, Feb. 24, 1931 (E. G. Anderson and A. S. Mills; Barber det.).

\section{PIGEON PEAS}

Moths of a bean pod-borer, Etiella zinckenella Treit., were several times reared from the pods in a planting near Río Piedras.

Heliothus virescens Fab. larvae were repeatedly found eating large holes into the green pods.

Larvae of a moth, Brachyacma palpigera Wlsm., were common during the summer and fall in dry pods and moths were reared from several localities. A proctotrupid parasite of the larvae, Paralitomastix n. sp. (Gahan det.) was found in as high as 50 per cent of the larvae in some collections made.

A legume pod-borer, Fundella cistipennis Dyar, was found moderately infesting a number of plants during July 1931 at Río Piedras.

A thrips, Frankliniella (=Euthrips) insularis Franklin, was found infesting pigeon-pea blossoms at Mayagüiez, Jan. 2, 1931 (H. Morrison det.).

The weevil, Callosobruchus chinensis L. was found working in dry pigeon-pea pods at Río Piedras, Aug. 8, 1930 (A. S. Mills; H. S. Barber det.).

A Phalacrid beetle, Olibrus sp., was commonly found breeding in dry pods at Río Piedras during July and August.

An adult of Hypothenemus sp. near parvus Hopk. (Blackman det.) was found boring inside a dry pod at Río Piedras, July 15, 1930 (A. S. Mills).

The beetles, Cathartus rectus L., $C$. advena Watl. and $C$. cassiae Reiche (W. S. Fisher det.), were all collected from inside dry pigeonpea pods at Bayamón, July 8, 1930 (A. S. Mills). 


\section{PINEAPPLE}

The pineapple mealy-bug, Pseudococcus brevipes Ckll. (det. Morrison) has been generally present but apparently neither common nor injurious. This according to specimens determined by Dr. Morrison for Dr. Woleott is not $P$. citvi Risso, but is what is listed in Wolcott's "Insectae Portoricensis" p. 281 as P. bromeliae Bouché.

The fire ant or "homiguilla brava", Solenopsis geminata Fab., has been generally present and in some cases at least doing some damage.

\section{POTATOES (IRISH \& SWEET)}

The potato flea-beetle, Epitrix cucumeris Harr. was present thruout Jan., Feb. \& March and increasing in numbers in several fields of Irish potatoes in Comerío, Adjuntas, Cidra, Caguas, and Río Piedras and especially in March did considerable injury.

The bug, Spartocera batatas Fab., injured experimental plots of Irish potatoes at Utuado in March; this is apparently its first record of injury to white potatoes in Porto Rico.

The spinach aphis, Myzus persicae Sulz., did considerable injury by the end of March to a small-patch of Irish potatoes near Río Piedras.

A leaf-beetle, Diabrotica graminea Baly, was fairly abundant on Irish potatoes at Comerío and Adjuntas early in March and at Cidra early in February.

The potato tuber moth, Pthorimaea operculella Zell, lightly infested a quantity of seed potatoes (Irish) which had been received from Prince Edward Island, Canada, and which had been stored under one of the buildings at the Station. The insect had apparently not been recorded as infesting Irish potatoes previously in Porto Rico.

The sweet potato weevil, Cylas formicarius Fab., was generally distributed and injurious as is usual, reports especially coming from Humacao, Carolina and Vieques Island.

The Scarabee, Euscepes batatae Waterh., was found in May to bc heavily infesting some sweet potato tubers in Carolina received for seed purposes from Mayagüez.

The sweet potato leaf-miner, Agromyza ipomeae Frost, was apparently present to some extent in practically all parts of the Island but not abundant enuf to be injurious.

Leafhoppers, apparently Empoasca sp., were usually observed in fair numbers wherever sweet potato plantings were examined but lit. tle injury seems to have been done. 
138 THE JOURNAL OF THE DEPARTMENT OF AGRICULTURE OF P. R.

RICE

The "changa", Scapteriscus vicinus Scudd., was reported as destroying about 50 per cent of the young plants in a 1-acre field at Juncos during April and into May; 3 acres of rice planted in early April 1930 in the same place were finally entirely destroyed by early July.

\section{ROSE}

A mealy-bug, Orthesia insignis Douglas, did considerable damage to a number of rose bushes in June in a garden in Santurce.

The cottony cushion scale, Icerya purchasi Mask. (Morrison det.), was found lightly infesting 50 rose bushes at Santurce, Feb. 24, (J. Luciano). The first record for Porto Rico.

June beetles, Phyllophaga spp., were reported as injuring several rose bushes at Ponce in early May by damaging the roots while burrowing for the purpose of egg-laying.

A leaf beetle, Metachroma antennalis Weise, was reported as doing very considerable damage to roses at Aguirre from April on; the beetles were present in enormous numbers, eating the flowers, leaves, and bark and over 400 out of about 1,000 bushes were practically destroyed.

\section{SUGAR CANE}

The sugar-cane moth-borer, Diatraea saccharalis Fab., did apparently the usual amount of damage which as probably, as far as could be determined, about the same as during the previous year or two. One large Central, however, near Hormigueros at the West end of the Island, reported a very high percentage of infested cane in many fields and stated that borer was worse than during the two years previous. As usual the percentage of cane infested was somewhat higher on the South Coast than in those parts of the North Coast having a higher rainfall. This statement is based upon many canes examined in several places during the harvest period from February to May 1931. At Aguirre and one or two other localities a rather high percentage of eggs were found infested with Trichogramma minutum Riley, but only a few eggs masses altogether were examined. Evidences of some parasitism by Lixophaga diatreae Towns. were also observed in almost every locality in which cane was examined, but no counts were made to determine percentages.

White grubs, Phyllaphaga spp., did about the usual amount of moderate damage. Altho the adults may not have been noticeably much less numerous than during the previous year or two it is the opinion of several of the larger sugar companies that white grubs 
are less injurious now than previously. The manager of a large Central near Aguadilla felt that the damage had been less this past year due to the imported toad, Bufo marinus L., eating the adults. Surveys in a number of cane fields in different parts of the Island showed that these toads eat large numbers of June beetles and' several large cane growers feel that they have been noticeably beneficial in white grub control. The adults were scarce at lights at Aguirre early in June and entirely absent late in the month.

The "vaquita", Diaprepes spengleri $\mathrm{L}$., eaused some stripping of young cane leaves as usual; one rather severe case of this was observed in Isabela but the young cane recovered due to abundant rains following the injury.

The yellow cane aphis, Sipha flava Forbes, caused very considerable damage in the western end of the Island from Isabela, Moca and Aguada to Cabo Rojo, Lajas, and Guánica. This started in December and gradually increased in severity thru Marel but during April, abundant rains following the pronounced dry spell, the infestation ceased. Not only Japanese cane but also POJ-2725 and 2878 were affected. At Aguada in March Cycloneda sanguinea $\mathrm{L}$. was common in infested fields but the pupae were highly infested by an undetermined Chalcid. Altho the extensive properties of the Aguirre Sugar Co. on the South Coast suffered a considerable dry spell during the winter, Mr. Herbert Osborne $\mathrm{Jr}$. and others reported the aphis not as bad as during the previous year.

The sugar-cane root-caterpillar, Perforadix sacchari Seín, was probably present in about the usual numbers. Moths were abundantly observed in one field near Mayaguiez in April among the cane on the ground just after cutting.

The sugar-cane scale, Aspidiotus sacchari Ckll, was generally distributed thruout variety experimental plots examined during April and May at Mayaguiez, Naguabo and Guayama, the percentage of cane infested at Mayaguiez being small but in the other two places about 10-12 per cent.

The pink leaf-sheath bug, Lasiochilus divisus Champ., was found fairly commonly and in all stages in a large experimental plot of several cane varieties examined in April near Mayagüez. Early in June adults were fairly common at light at Aguirre but late in the month were scarce.

The West Indian cane weevil, Metamasius hemipterns L., was probably generally present but was observed (in cane being harvested) only at Mayagüez (light infestation) in April and fairly common at Guayama. 
The sugar-cane mealy bug, Pseudoccoccus sacchari Clkll, was observed more or less commonly at harvest time (February-May) in several localities on the North and South Coast and West end of the Island, but was apparently somewhat more common in the south.

The red-striped sugar-cane scale, Pulwinaria iceryi Guer., was found infesting the leaves of some sugar-cane plants in one of the greenhouses at the Station at Río Piedras in March.

The adults of the Scarabeid beetle, Dyscinetus barbatus Fab., known to attack sugar cane, were abundant at lights at Isabela for a few weeks, being first noticed abont the middle of April, but became scarce the middle of May and soon after failed to appear any more.

A leaf-hopper, Protalebra brasiliensis De Long, listed as a minor pest of sugar cane in Porto Rico, was abundant thruout June on large patches of a. weed, "margarita" or "clavelillo" (Bidens pilosa) on the golf course at San Juan but was searce at the Station at Río Piedras.

The Scarabeid beetles, Ligyrus tumulosus Burm., were common at light early in June at Aguirre but scarce the end of the month.

\section{SWORD BEAN (Cannavallia. sp.)}

The cowpea pod and stalk borer, Fundella cistipennis Dyar, was reported as moderately infesting the pods in a patch at Florida during the latter part of April.

\section{TOBACCO}

The tobacco leaf-miner, Phthorimaea operculella Zell., did considerable damage, more so than usual due to unusually dry weather, around Comerío and Caguas, and also in one field near Río Piedras during February, March and April.

The tobaceo hornworm, Protoparce sexta Joh. var. jamaicensis Butler, was undoubtedly generally present as ustal; it was reported specifically as having completely stripped the leaves from a 2 -acre planting at Juncos during April; no attempt at control had been made.

The "changa", Scupteriscus vicinus Scudder, was generally present and more or less injurious. In the Juneos-Las Piedras tobaceo section it was reported as killing about 15 per eent of the young plants in the field during November and December which is said to be about the usual amount of damage there.

Climbing cutworms, Noctuidae, were reported as more injurious 
than usual to young plants in the Juncos $\perp$ Las Piedras section, killing about 20 per cent during November and December.

Flea-beetles, Epitrix cucumeris Harr. and E. parvula Fab., were very injurious to seed-beds at the Station in September and October but present and injurious also to plants in the field during the winter. They were also generally distributed and injurious throughout the growing season (winter and spring) in the tobacco sections. Damage was reported as light during the winter to seedbeds in the Juncos-Las Piedras district. Early in May some damage was just starting to late tobacco in the field around Humacao.

\section{TOMATO}

The corn earworm, Heliothis obsolete Fab., was observed moderately injuring tomato fruits during January or February at both Río Piedras and Arecibo.

A plant-bug, Phthia picta Drury, was present in all stages and puncturing about 50 per cent of the fruits in a small patch of tomatoes at Río Piedras in January or February. A single plant at the Demonstration Farm at Mayagüez had all stages present in abundance in April, but little damage had been done.

Nezara viridula L. was observed injuring about 20 per cent of the fruits in the same garden patch at Río Piedras in December (A. S. Mills).

An adult of the bug, Thyantor perditor Fab., was found feeding. on tomato fruit at Corozal Feb. 5, 1931 (A. S. Mills; H. G. Barber det.).

Cutworms, Noctuidae, eaused about 10 per cent loss to plants in seed-beds in greenhouses at the Station in September and October and about 20 per cent to young plants after being set in the field.

The leaf-tyer, Pachyzancla perusialis Walk, was present in the field but more injurious to a number of experimental plants grown in the greenhouse thruout the year.

The potato and tomato flea-beetle, Epitrix cucumeris Harr., was generally present and sometimes doing considerable injury.

"Changas", Scapteriscus vicinus Scudd., were reported as doing considerable injury to young tomato plants at Isabela.

\section{WEST INDIAN LAUREL (Ficus nitida)}

The mealy-bug, Icerya montserratensis Riley and Howard, was observed badly infesting one or two of a number of large trees in the Plaza at Caguas in April. It was probably present during the 
year since several subsequent examinations showed it to be about the same.

A thrips, Gynaikothrips uzely Zimm $=\ll$ Mesathrips ficorum Marchal» was observed abundant as usual in several parts of the Island, often considerably curling the leaves.

\section{WEST INDIAN FRUIT FLIES}

One species of Anastrepha was generally distributed and as abundant as usual. The jobo or hog plum, Spondias mombin, is its most favored host and is always found infested from June to December, the period of ripe fruits. Ciruelas, Spondias cirouella and S. purpurea, were also commonly infested during their fruiting season, August thru October, but not quite so heavily. Certain varieties of native and imported mangos were commonly infested from April thru June; certain other varieties, heretofore always reputed to be immune, have remained so, as far as observations could determine. It also breeds to some extent in guavas.

Another species has been found breeding commonly in pomarrosa, Jambos Jambos, during April and May, apparently being its favorite foodplant. Bitter almond, Terminalia cattapa, was also found infested during April thru August 1931 but only in a comparatively few fruits at Río Piedras and Arecibo. This is commonly found in guavas. (F. Seín, Jr.)

\section{MISCELLANEOUS RECORDS}

The following records are from interceptions made by the United States Plant Quarantine and Control Administration office in San Juan during the fiscal year. Altho not primarily of economic importance they constitute in most cases new or interesting records for the Island:

A scale, Conchaspis angraeci Ckll. (Morrison det.), heavily infesting the branches of an undetermined tree at Río Piedras, July 7, 1930 (A. S. Mills). Listed previously only on vanilla at Mayagüez (1917) and ornamental croton at Mameyes (1912).

A predacens bug, Coreocoris fusca Thunberg (H. G. Barber det.) adults and nymphal instars on a weed, Bayamón, Aug. 8, 1930 (A. S. Mills). Not in Wolcott's "List".

Several adults of a Cynipid, Eucoila (Hexamerocera) hookeri (L. H. Weld det.) were reared from jobo fruits infested with Anastrepha sp. at Mayagüez, Sept. 21, 1930 (A. G. Harley). Not in Wolcott's "List". 
An adult of Opius anastrephae Vier. (A. B. Gahan det.) also reared from jobo, Spondias lutea, as above.

An ant, Tapinome littorale Wheeler (W. M. Mann det.) in dry leaves at Aguas Buenas near the mouth of the caves, Oct. 1930 (A. S. Mills).

An Anthomyid fly, Atherigona excisa Thomson (Aldrich det.) reared from larvae in decayed areas in string-bean pods from Isabela, collected Sept. 20, 1930 (Faxon and Mills); also reared from 7 larvae in tomatoes for export, Borinquen (near Aguadilla) Jan. 12, 1931. Not in either Wolcott's or Curran's "Lists".

The vinegar fly, Drosophila ampelophila L. (C. T. Green det.) reared in numbers from string bean pods as above; also 3 adults on a banana leaf Maricao, Dec. 11, 1930 (A. G. Harley). Not previously reported from Porto Rico.

The Nitidulid beetles, Stelidota geminata Say and Scymnillodes gilvifrons Chpn. (E. A. Chapin det.), were found in a decayed area in an orange at Barceloneta, Dee. 12, 1930 (Faxon and Mills). The former is little known in Porto Rico and the latter is not in Wolcott's "List".

Nitidulid Haptonchus luteolus Er. (Chapin det.), adults were found in decayed fruits of Inga laurina at Santurce, Dee. 19, 1930 (E. G. Anderson and A. S. Mills).

A large nymph of an earwig, Anisolabis annulipes Lucas (A. N. Caudell det.) was taken in the above fruits also.

An Ortalid fly, Euxesta stigmatius Loew. (Aldrich det.) was reared from an ear 'of corn Sept. 12, 1930 from Río Piedras (A. S. Mills). The locality is new for Porto Rico.

A Reduvid bug, Zelus longipes L. (H. S. Barber det.) collected on a pepper leaf Nov. 4, 1930, at Arecibo (A. S. Mills).

A Trypetid fly, Xanthaciura phoenicura (Aldrich det.) on a grapefruit leaf at Añasco, Nov. 5, 1930 (A. G. Harley). Not previously reported from Porto Rieo.

A Coreid bug, Chariesterus gracilicomis Stal (H. G. Barber det.) found resting on a grapefruit leaf at Anasco Nov. 5, 1930 (A. G. Harley).

A Calliphorid fly, Morellia violacea Fab. (Aldrich det.), 3 adults collected from orange foliage, Maricao, Dec. 18, 1930 (A. G. Harley). Not previously reported from Porto Rico.

A Trypetid fly, Euaresta melanogaster Lw. (Aldrich det.) swept from grass in an orange grove, Maricao, Dec. 26, 1930 (A. G. Harley). Little known in Porto Rico.

A Psocid, Embidopsocus lutens Hagen (Caudell det.). Numerous 
144 THE JOURNAL OF THE DEPARTMENT OF AGRICULTURE OF P. R.

adults and nymphs in cereal in a glass jar, San Juan, Dec. 25, 1930 (Faxon and Mills).

An adult of the butterfly, Lycaena cassius Cramer (Shaus det.) on a bean leaf, Manatí, Jan. 16, 1931 (Anderson and Mills). Recorded only once, from Camuy.

An earwig, Psalis americana var. gagathina Burm. (Caudell det.), 1 female in decayed trunk of banana, Maricao, Jan. 24, 1931 (Harley, Faxon and Mills). A new locality record.

A Nitidulid beetle, Lobiopa insularis Cast. (Böving det.) young larvae in jobo fruits, Río Piedras, Jan. 26, 1931 (Faxon and Mills). A Stratiomyd fly, Neorondania chalybea Weid. (C. T. Greenè det.) taken on a potato leaf, Cidra, Feb. 18, 1931 (Faxon and Mills). Previously listed only from Río Piedras.

A Coccinellid beetle, Cycloneda limbifer Csy. (E. A. Chapin det.), adult on eggplant, Caguas, Feb. 13, 1931 (Faxon and Mills). Not listed previoúsly from Porto Rico.

A Coccinellid, Neda ferruginea Oliv. (E. A. Chapin det.), adult on cotton leaf, Ponce, Mar. 13, 1931. (Faxon and Mills).

A Coceinellid, Scymmus loewii Muls. (E. A. Chapin det.), several adults in a box of peppers from Vega Baja, Mar. 7, 1931 (Faxon and Mills). 